\title{
Peak pressure determined from staurolite-chloritoid metapelites in the Monte Rosa nappe: thermodynamic and geodynamic implications
}

\section{J.D. VAUGHAN-HAMMON1*, C. LUISIER2, S.M.} SCHMALHOLZ1, L.P. BAUMGARTNER1

1 Institute of Earth Sciences, University of Lausanne, Lausanne 1015, Switzerland (*joshua.vaughanhammon@unil.ch)

2 Université de Rennes, 35042 Rennes, France

Pressure recorded in metamorphic rocks is typically assumed to represent a hydrostatic stress and thus dependent on depth only. Recently work in the Monte Rosa nappe (European Alps) has challenged this lithostatic assumption. Observable pressure differences of $0.8 \pm 0.3 \mathrm{GPa}$ between chloritoid, talc, and phengite-bearing lithologies ('whiteschists') at ca. $2.2-2.5 \mathrm{GPa}$, and metagranite lithologies at $1.4 \mathrm{GPa}$ are recorded [1]. We present newly discovered staurolite-chloritoid bearing metapelites from the Monte Rosa nappe, in order to constrain the peak conditions during burial within the Alpine orogeny and the resulting tectono-metamorphic and geodynamic implications.

Phase petrology calculations have been undertaken on staurolite, chloritoid, phengite and paragonite assemblages. However, non-negligible amounts of $\mathrm{ZnO}$ in staurolite have been recorded $(\sim 5 \%$ wt $\%$ and $\sim 1$ a.p.f.u). Due to the lack of solution models for Zn-staurolite end-members we have calculated a range of mixing models in order to adjust the activity for existing $\mathrm{Fe}$ and $\mathrm{Mg}$ end-members. Neglecting $\mathrm{Zn}$ entirely, results in $1.6 \pm 0.1 \mathrm{GPa}$ and $600 \pm 5^{\circ} \mathrm{C}$, whereas a highly non-linear mixing model results in $1.6 \pm 0.2 \mathrm{GPa}$ and $580 \pm 15^{\circ} \mathrm{C}$. These findings confirm the presence of significant diaprities in pressure of $0.6 \pm 0.2 \mathrm{GPa}$ within the coherent nappe.

We argue that the maximum burial depth of the Monte Rosa unit was significantly less than $80 \mathrm{~km}$ (lithostatic 2.2 GPa). Rather, the maximum burial depth of the Monte Rosa unit was presumably less than $55 \mathrm{~km}$, from pressures of 1.4 1.6 GPs recorded frequently in metagranite and metapelitic lithologies. This depth is compatible with burial and exhumation within an orogenic wedge, and relatively slower exhumation rates from shallow crustal depths.

[1] Luisier, C., Baumgartner, L., Schmalholz, S.M., Siron, G., Vennemann, T., 2019. Nature Communications, 10(1): 4734. 